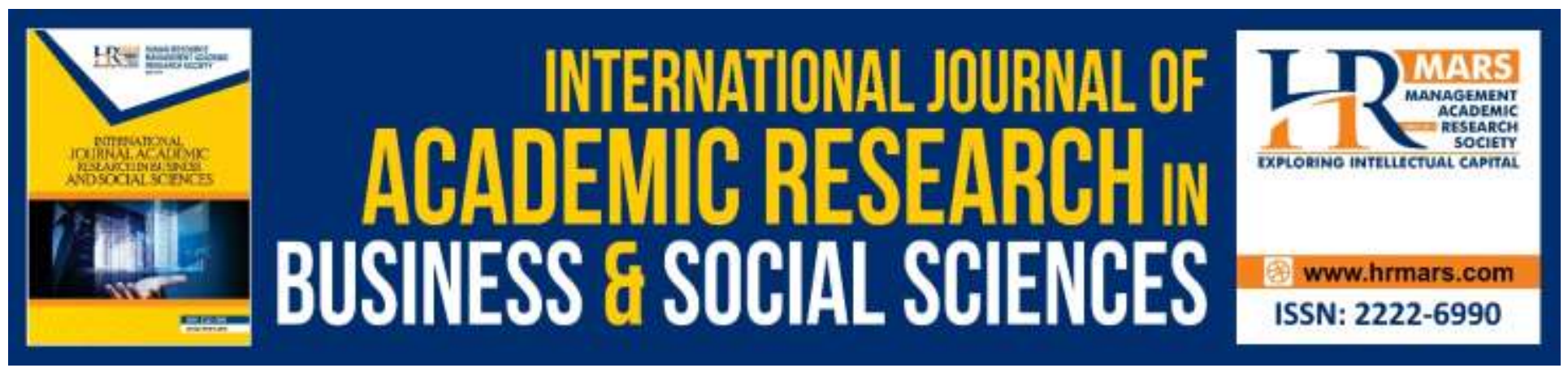

\title{
Entrepreneurial Intention among Community College Students: A Conceptual Attempt to Understand Early Adoption of Entrepreneurial Career
}

Shathees Baskaran, Salmianti Mutalib, Saratull Nor Natasha Safri and Nomahaza Mahadi

To Link this Article: http://dx.doi.org/10.6007/IJARBSS/v9-i6/5991

DOI: $10.6007 /$ IJARBSS/v9-i6/5991

Received: 09 April 2019, Revised: 12 May 2019, Accepted: 01 June 2019

Published Online: 28 June 2019

In-Text Citation: (Baskaran, Mutalib, Safri, \& Mahadi, 2019)

To Cite this Article: Baskaran, S., Mutalib, S., Safri, S. N. N., \& Mahadi, N. (2019). Entrepreneurial Intention among Community College Students: A Conceptual Attempt to Understand Early Adoption of Entrepreneurial Career. International Journal of Academic Research in Business and Social Sciences, 9(6), 744-758.

Copyright: (C) 2019 The Author(s)

Published by Human Resource Management Academic Research Society (www.hrmars.com)

This article is published under the Creative Commons Attribution (CC BY 4.0) license. Anyone may reproduce, distribute, translate and create derivative works of this article (for both commercial and non-commercial purposes), subject to full attribution to the original publication and authors. The full terms of this license may be seen at: http://creativecommons.org/licences/by/4.0/legalcode

Vol. 9, No. 6, 2019, Pg. 744 - 758

http://hrmars.com/index.php/pages/detail/IJARBSS

JOURNAL HOMEPAGE

Full Terms \& Conditions of access and use can be found at http://hrmars.com/index.php/pages/detail/publication-ethics 


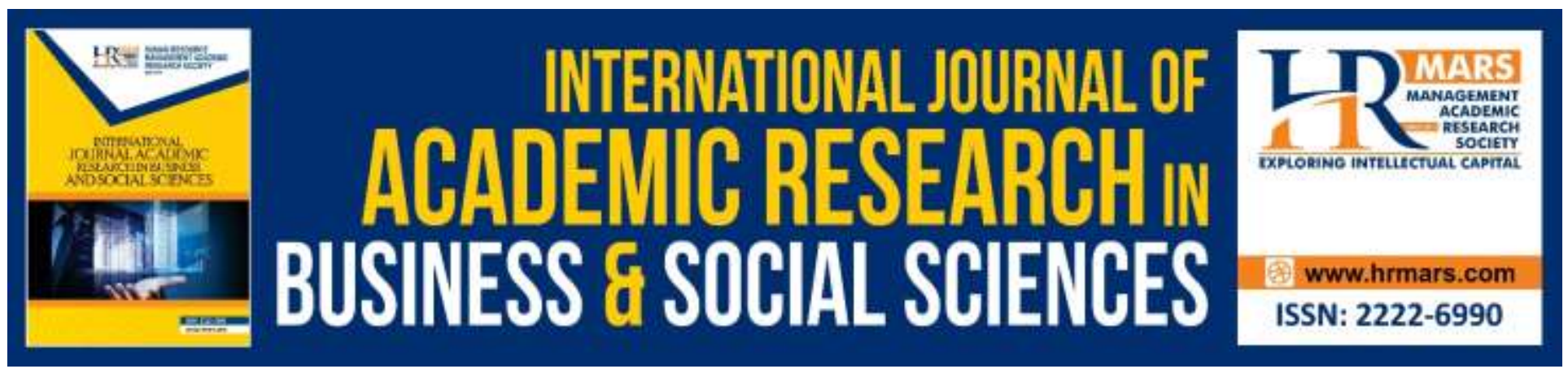

\title{
Entrepreneurial Intention among Community College Students: A Conceptual Attempt to Understand Early Adoption of Entrepreneurial Career
}

\author{
Shathees Baskaran, Salmianti Mutalib, Saratull Nor Natasha Safri \\ and Nomahaza Mahadi \\ International Business School, Level 10, Menara Razak, Universiti Teknologi Malaysia, \\ Jalan Sultan Yahya Petra, 54100 Kuala Lumpur. \\ Email: shathees@utm.my
}

\begin{abstract}
A desire to engage in entrepreneurial endeavours is merely a behavior, which is intentionally planned. In this vein, competing models have been reported in the literature in an attempt to understand entrepreneurial intention phenomenon with Shapero's model of the entrepreneurial event taking the lead followed by Ajzen's Theory of Planned Behavior. The former model emphasized perceived desirability, perceived feasibility and propensity to act while the latter model introduced personal attitude, subjective norm, and perceived behavior although conceptually both models' proposed constructs are somewhat similar or identical. These constructs are widely used in the literature to understand the entrepreneurial intention in various contexts. However, viewing it from an academic institution's perspective flagged that entrepreneurial education is equally important in activating entrepreneurial intention among students who are nascent entrepreneurs of the future. Therefore, this study is an attempt to suggest a conceptual framework linking entrepreneurial tendency driven by the Theory of Planned Behavior and entrepreneurial intention. Additionally, entrepreneurial education is proposed as a mediator in understanding the relationship between entrepreneurial tendency and entrepreneurial intention. This research also offers relevant supporting literature and direction for future empirical investigation in order to contextualize this study.
\end{abstract}

Keywords: Entrepreneurial Intention, Entrepreneurial Education, Entrepreneurial Tendency, Subjective Norm, Perceived Behavior, The Theory of Planned Behavior

\section{Introduction}

The National Higher Education Strategic Plan has outlined entrepreneurship as a catalyst for transformation aimed at contributing to the improvement of the quality of higher education institutions of the country. Malaysia's transformation from a knowledge-based economy to an 
innovation-based economy in achieving the aspiration to become a developed and high-income nation requires the support of quality and competitive human capital. Ministry of Higher Education in the past had launched the Higher Education Institution Development Policy in 2010, in recognition of the importance of entrepreneurship to a nation. The policy was aimed at promoting more holistic entrepreneurship education and development among Higher Education Institutions. Implementation of the policy-based initiative is expected to produce graduate/postgraduate from Institutions of Higher Education with entrepreneurial value, entrepreneurial thinking, and entrepreneurial attributes. Besides, indirectly it will increase the number of potential entrepreneurs among graduates of Higher Education Institutions. This involvement in the business is a catalyst for the achievement of the transformation of the national economy from the middle-income economy to a high-income economy and at the same time produce graduates and postgraduates with value, skills, thinking and attributes along with an entrepreneurial mindset. In line with the government's goal, various efforts have been made in the form of education, programs, and entrepreneurial culture activities among students of public institutions of higher learning.

Community College is a government agency under the Ministry of Higher Education providing a wide range of training and skills at all levels especially on Technical and Vocational Education Training (TVET) courses. It also gives chances to post-secondary education before entering the career life or continuing study to a higher level. In addition, Community Colleges also provide short courses for rural communities to gain and enhance their skills. On 5 July 2000, Minister of Education submitted the Memorandum No. 398/2225/00 to the Cabinet for Community College establishment. Ministry of Education also proposed that Community College established in every parliamentary district in Malaysia. In 2001, there were twelve pioneers Community Colleges began operating in the whole of Malaysia. Cabinet has agreed to make Community Colleges as Lifelong Learning Hub starting 2004. Since the establishment in 2001, the number of Community Colleges has risen to 94 across all states in Malaysia. Community College vision is being a leader in the Education and Training Technical and Vocational Education and Lifelong Learning Hub by 2025. While Community College mission is to build the local community as a knowledgeable and skilled workforce to meet, the demands of the working world through Education and Technical and Vocational Training and Lifelong Learning.

In order to support Higher Education Institution Development Policy, the Community College Education Department has devised a strategy to uphold the community college by introducing the Community College Entrepreneurship Reinforcement Plan. The plan focuses on creating Community College students and local communities with the characteristics and competencies of entrepreneurship, competitive and self-esteem in line with the Higher Education Institution Development Policy. The main goal of this plan is to provide guidelines for implementing entrepreneurship programs at Community College in order to create more human capital with entrepreneurial thinking, attributes, and value. Community College Entrepreneurship Reinforcement Strategic Plan based on six core Higher Education Institution Development Policies as follows: i. Establish an entrepreneurship center at Community College Education Department and Community College, ii. Providing well-organized and holistic entrepreneurship education and programs, iii. Strengthening entrepreneurial development and consolidation programs, iv. Creating an effective 
INTERNATIONAL JOURNAL OF ACADEMIC RESEARCH IN BUSINESS AND SOCIAL SCIENCES Vol. 9, No. 6, June, 2019, E-ISSN: 2222-6990 @ 2019 HRMARS

measurement mechanism, v. Providing a conducive environment and ecosystem for entrepreneurial development, and vi. Strengthen the competence of entrepreneurship coordinators.

In the past, the Community College Education Department has taken the initiative to set up a Community College Entrepreneur Centre to regulate entrepreneurial activities at Community College throughout Malaysia. With the establishment of this Centre, the E-Tech Centre is being developed at each college to regulate and organize entrepreneurial activities at their respective college. Indirectly, students are exposed to entrepreneurship through informal education. The involvement of students in the field of entrepreneurship while studying is necessary as a process of disclosure to apply the characteristics and culture of entrepreneurship within the student. This is aimed at preparing them to venture into entrepreneurship as well as to increase their competence to face the increasingly challenging human capital competition after completing their studies. Parallel with this, Community Colleges provide a lot of programs that are based on TVET at certificate and diploma levels.

\section{Problem Statement}

According to the Statistics Department of Malaysia, the unemployment rate in Malaysia up to May 2019 is 3.3\%. The issue of unemployment among graduates in Malaysia is a common debate lately. Graduate unemployment is basically driven by the situation of the economic structure itself. Employment opportunities are created in an economy based on several factors. Among the factors that can spur the job sector are good economic growth, positive optimism and prospects on future opportunities by traders as well as the influx of foreign investments that help create new jobs. The current economic situation is a key indicator in determining the direction and demand for the employment and labour sectors. In the meantime, the uneven gap between the supply of labour and the demand from both the public and private sectors resulted in some labour unemployment. In challenging economic situations, graduates are less likely to experience difficulties in finding jobs than in older adults. This development is commonplace in almost every country and not a new phenomenon. In the meantime, it should be emphasized on job opportunities created and offered by the public and private sectors. These job opportunities are based on current needs such as replacement or new job due to company development. In order to ensure that employment opportunities continue to be generated by the private sector, a sustainable approach needs to be planned. This involves actions and efforts to apply entrepreneurship culture among the general public and adolescents in particular. The intention of the business world not only contributes to economic development but also creates job opportunities. The increase in the number of businesses directly increases the supply in the employment sector. The Global Entrepreneurship Monitor (GEM) study report 2018 monitors' entrepreneurial activity by using three indicators: Total early-stage entrepreneurial activity (TEA), the proportion of established businesses (EB) among the respondents and entrepreneurial employee activity (EEA). The report posted Malaysia in second place from the early stage of entrepreneurial activity. This means that the tendency to start a business among young people in Malaysia is very low. According to the study, only 4.9 percent of them aged between 18 and 64 years are planning to venture into business. The results have not been encouraging. 
From the findings of the study, in general, it can be concluded that with the lack of inclination towards entrepreneurship by Malaysians, the potential for new employment opportunities will diminish in the future. This development needs to be carefully studied because, in view of the experience of developed countries, the tendency towards entrepreneurship clearly plays a major role not only in terms of providing job opportunities, even being a catalyst agent in producing high innovation results. If viewed from the perspective of the structure of entrepreneurship ecosystems in Malaysia, many efforts are being made in applying interest in becoming entrepreneurs. The initiative, however, has not yet shown impressive results. In view of the potential that can be generated from this entrepreneurial field, it is not only able to generate domestic economy but even solve the issue of unemployment among adolescents. Therefore, serious emphasis should be placed on initiatives aimed at applying entrepreneurial culture and producing successful entrepreneurs. Therefore, the research objective of this study is to identify the factors that influence on Community College students' entrepreneurial intentions.

\section{Literature Review \\ Entrepreneur}

In different contexts, definitions for entrepreneur terms vary. For economists, entrepreneurs are someone who brings resources, workers, materials, and other assets to a combination that gives them a higher value as well as introducing new changes, innovations, and directives. For psychologists, entrepreneurs refer to people who are usually guided to achieve and gain something, test, implement or avoid the power of others (Mohar et al., 2007). Hisrich and Peters (1995) explain that an entrepreneur means to carry out tasks, responsibilities or attempts (Makhbul \& Hasun, 2003). Aishah (2002) defines entrepreneurs as one who strives to produce something new, different and valuable that is accepted by the community by using all available resources and taking on financial, psychological and social risks to obtain rewards in the form of financial and personal satisfaction. From all the above definitions, it is clearly evident that everyone has the chances to become an entrepreneur. The aspect that distinguishes between entrepreneurs and non-entrepreneurs is their willingness to blend creativity, innovation, and risk-taking with the sincerity of working to shape, develop and maximize the potential of them by exploiting the opportunities it earns.

\section{Entrepreneurship}

Dollinger (1995) cited that Schumpeter (1934) defines entrepreneurship as a company that implements new combinations for the development of new products and services, new sources of raw materials, new production methods, new markets, and new-formed organizations. Cole (1968) defines entrepreneurship as an activity that benefits through profit-oriented business development. Stevenson, Roberts, and Grousbeck (1989) have given a more dignified definition of entrepreneurship as an individual's readiness to seize opportunities without taking into account the current resources available in his control. From the various definitions, Dollinger (1995) define entrepreneurship as the creation of innovative economic companies with profit or development goals and the willingness to deal with non-discrimination risks. Schaper, Volery, Weber, and Lewis (2010) defined entrepreneurship as the process, brought about by individuals, of identifying new entrepreneurial opportunities and converting them into marketable products or services. The definitions given above 
reflect that entrepreneurship has a close connection with the efforts of forming, reforming and development to create new combinations in carrying out activities related to it. Researches have shown that entrepreneurship process is an essential source of developing human capital and learning opportunities for individuals to improve their skills, attitudes, and abilities (Shane 2003; Brana 2008; Ekpoh \& Edet, 2011). There is also a consensus among scholars that entrepreneurship is important in promoting and stimulating economic development and employment generation. Abdul Aziz (2003) stated that participation in entrepreneurship is satisfaction in an individual. Entrepreneurs will only be satisfied when they achieve desired self-esteem. Therefore, to achieve satisfaction, an entrepreneur must be willing to use all the opportunities, resources and potentials available. Entrepreneurs need the power to mobilize resources to achieve all goals set. Entrepreneurship can free the individual from being shackled by forces that can restrict the growth of creative ideas. Through the definitions and explanations discussed above, entrepreneurship in the Malaysian context has a close association with the development and development efforts in line with the technological change. This is intended to create new alternatives in carrying out activities related to them.

\section{Entrepreneurial Intention}

Krueger and Carsrud (1993) defined entrepreneurial intention as the target behavior of starting a business. Katz and Gartner (1988) define entrepreneurial intention as the search for information that can be used to fulfill the goal of venture creation. Intentionality is a state of mind directing a person's attention, which leads to experience and action in order to achieve something (Bird, 1988). Wu and $\mathrm{Wu}(2008)$ stated that entrepreneurial intention is a state of mind that enables people to create a new firm or a new value driver inside existing organizations through voluntary behavior. In understanding the entrepreneurial intention phenomenon, Ajzen's Theory of Planned Behavior (TPB) has been widely used to explain and predict engagement and reluctance to embark on entrepreneurship behavior.

\section{Entrepreneurial Tendency}

According to Douglas and Shepherd (2002), the tendency for entrepreneurship relates to individual attitudes toward risk and self-reliance. A person with high entrepreneurial tendency will show a more positive attitude toward risk and self-reliance. In other words, one's tendency towards something can push their desire to get what is being aimed for. In this case, if the individual has a tendency to embark into an entrepreneurial career, then the probability of engaging in entrepreneurship is also found to be very high. This is because positive attitudes are able to stimulate the level of individual desire to exhibit further action by choosing entrepreneurial careers. It is also acknowledged by Hisrich et al., (2008) who believe that individuals who have a strong tendency to do something will show a positive likelihood of the desired action. In entrepreneurship studies, there are various linked concepts including Van Auken et al., (2006) explaining the tendency of entrepreneurship and Segal et al., (2005) linking it to motivation. Therefore, the entrepreneurial tendency is examined since it has an important impact in influencing one's decision to become an entrepreneur. 


\section{Theory of Planned Behavior}

The literature has indicated that there are a number of competing models that attempts to explain behavioural intention discussing similar or identical constructs. In view of this, an initial attempt to understand the entrepreneurial intention was driven by Shapero's model of the entrepreneurial event (SEE) (Shapero \& Sokol, 1982). This theory premises that intention to engage in the entrepreneurial event is driven by three important antecedents: perceived desirability, perceived feasibility, and propensity to act. Nevertheless, the Theory of Planned Behavior (TPB) by Ajzen (1991) is the widely operationalized and examined model in the entrepreneurship literature. Therefore, this study is proposed based on the TPB which is one of the most popular conceptual frameworks for the study of individuals' entrepreneurial intentions (Linan \& Chen, 2009; Krueger \& Carsrud, 1993). The Theory of Planned Behavior outlines that the attitude towards the act, social norms, and perceived behavioral control are the three key factors that influence an individual's intention to perform a given behavior. To some extent, conceptually, attitude and perceived behavioral control in TPB are homologous to perceived desirability, perceived feasibility in SEE. TPB theory posits that entrepreneurial behavior is a function of entrepreneurial intentions. According to Vesalainen and Pihkala (1999), entrepreneurial intention refers to either creating a new venture or creating new values in existing ventures. Thandi and Sharma (2004) suggest that a person's attitude towards becoming an entrepreneur, subjective norms (perception of others), and behavioural control are antecedents of intention. Thus, the more favourable the attitudes and subjective norms are and the greater the perceived behavioural control is, the stronger the intention to perform the behaviour. These have been widely tested and shown to have a significant effect in predicting entrepreneurial intentions (Krueger et al., 2000).

\section{Personal Attitudes}

Personal attitudes refer to individual attitudes of either positive or negative in making decisions on what area they want to invest (Ajzen 1991, 2002). In addition, Kalafatis et al (1999) emphasized that personal attraction of the expected amount of revenue is taken into account allowing the intentions or subsequent intentions towards entrepreneurial tendencies. Similar concepts were also emphasized by Linan et al., (2007). This shows that personal attraction depends on the individual itself. Previous studies have consistently supported positive relationships between personal attitudes and entrepreneurial intentions (eg, Ajzen, 1991; Krueger \& Carsrud, 1993; Linan et al., 2007). According to Maes et al., (2014), there are influences of personal attitudes in invoking entrepreneurial intention. This is more evident among students who are inclined to choose entrepreneurship as their career choice driven by their positive attitude towards entrepreneurial opportunities (Mumtaz et al., 2012). Therefore, it can be inferred that personal attitude has a high tendency to create entrepreneurial intention among students.

\section{Subjective Norms}

According to Ajzen (1991, 2002), subjective norms are the environmental influences that affect the actions of an individual to respond positively or vice versa. The influence of this environment, among others, consists of peers, families, political parties, religious organizations, and others. It means that if an individual is affected by the individual in his or her environment or the individual in the 
INTERNATIONAL JOURNAL OF ACADEMIC RESEARCH IN BUSINESS AND SOCIAL SCIENCES Vol. 9, No. 6, June, 2019, E-ISSN: 2222-6990 @ 2019 HRMARS

environment supports his or her involvement, then they will have the tendency to inherit the norms of the environment. Several scholars (e.g. Ajzen, 1991; Krueger \& Carsrud, 1993; Linan et al., 2007) provided evidence in support of strong positive relationships between subjective norms and entrepreneurial intentions.

\section{Perceived Behavior}

Control of regulated behavior refers to the degree of difficulty in executing a behavior that affects the individual's confidence in doing what he or she has (Ajzen, 1991, 2002; Kalafatis et al., 1999). The same concept was debated by Bandura (1977) through Theory of Social Learning and Shapero and Sokol (1982) through Self-Contained Efficiency Theory. The argument by Krueger and Carsrud (1993) through behavior control theory emphasizes that the tendency element can be used to measure behavior control. Attitude can influence behavior and this leads to such a tendency. Behavior control theory has been used in the past to predict entrepreneurial intentions (Kolveroid, 1996). Maes et al. (2014) clarified further that perceived behavior encompasses internal and external control beliefs. While internal control beliefs are driven by personal capabilities (e.g. self-confidence), external control which is also known as situation control is driven by situational characteristics. In support of this, Soutaris et al., (2007) indicated that students generally tend to possess high self-confidence which represents their strong perceived behavior towards entrepreneurship.

\section{Entrepreneurial Education}

People gain knowledge, develop abilities, and have more opportunities to improve their quality of life through education. That is why education plays a vital role in teaching and developing entrepreneurial skills (Acs et al., 2014). Shephered and Douglas (1977) defined entrepreneurship education as the capability to visualize and a blueprint for a new business venture by searching information from the functional discipline and from the external environment in the context of the extraordinary riskiness and uncertainty which faces a new business venture. Entrepreneurship education is also defined as a model of education involving the collection of sub-elements (concepts) that provide a contribution to the conception of entrepreneurship education. The Consortium for Entrepreneurship Education (2008) stated that entrepreneurship education is about encouraging creative thinking and promoting a strong sense of self-worth and empowerment. Through entrepreneurship education, students learn a lot of things apart from learning about how to create a business. The core knowledge created through entrepreneurship education includes the ability to i. recognize opportunities in one's life, ii. pursue opportunities by generating new ideas and find the needed recourses, iii. create and operate a new firm and iv. to think in a creative and critical manner. Keogh and Galloway (2004) stated that entrepreneurship education is one of the important mechanisms to provide students with modern economics, where business skills are important. Entrepreneurial education is an education that contributes to improving the quality of students to start a business through social attitudes and intellectuals in entrepreneurship given at higher educational institutions. Entrepreneurial education does not only considers the contents of the program but also other contexts such as programs facilitated by lecturers and the approaches they use (Pretorius, 2000). Evaluation of the effectiveness of the methods of teaching and learning in entrepreneurial education is important to identify whether the method is appropriate to students, 
institutions, and countries, in general, is to increase the number of entrepreneurs. Entrepreneurs are not born naturally or they cannot be inherited as they are not influenced by genetic factors. However, entrepreneurship can be shaped from a young age through the education system and family support. According to a study conducted by Carter and Collinson (1999), educational institutions play an important role in providing formalized entrepreneurship education in promoting entrepreneurial activity among students. In support of this, Aishah (2002) stated that entrepreneurship education usually aims to identify, shape and influence children with potential entrepreneurial characteristics to become entrepreneurs.

\section{Research Prepositions}

\section{Entrepreneurial Education and Entrepreneurial Intention}

Entrepreneurship education in creating future entrepreneurs has been a main concern since the last decade. There are many studies conducted in order to understand the broad nature and driving factors in understanding this phenomenon. Table 1 provides a summary of studies conducted in understanding entrepreneurial education and also entrepreneurial intention since the past decade.

Table 1: Entrepreneurial Education and Entrepreneurial Intention

\begin{tabular}{|c|c|c|}
\hline Author & Research Objective & Research Findings \\
\hline $\begin{array}{l}\text { Souitaris, } \\
\text { Zerbinati, and } \\
\text { Al-Laham } \\
(2007) \\
\end{array}$ & $\begin{array}{l}\text { To test the effect of } \\
\text { entrepreneurship programs on } \\
\text { entrepreneurial attitudes and } \\
\text { intentions of students }\end{array}$ & $\begin{array}{l}\text { The entrepreneurship programs raise } \\
\text { some attitudes and overall } \\
\text { entrepreneurial intentions of } \\
\text { students }\end{array}$ \\
\hline $\begin{array}{l}\text { Balaban and } \\
\text { Ozdemir (2008) }\end{array}$ & $\begin{array}{l}\text { To determine the factors affecting } \\
\text { the entrepreneurial intentions of } \\
\text { students of business } \\
\text { administration and the relation } \\
\text { between the intentions and the } \\
\text { entrepreneurship } \\
\text { education/courses }\end{array}$ & $\begin{array}{l}\text { Entrepreneurship education is a } \\
\text { sufficient condition for the } \\
\text { emergence of entrepreneurial } \\
\text { intentions }\end{array}$ \\
\hline $\begin{array}{l}\text { Wu and Wu } \\
(2008)\end{array}$ & $\begin{array}{l}\text { To examine the relationship } \\
\text { between university students' } \\
\text { higher educational background and } \\
\text { their entrepreneurial intention }\end{array}$ & $\begin{array}{l}\text { Students who had entrepreneurship } \\
\text { education show a greater intention } \\
\text { to start up a new business than those } \\
\text { who did not have }\end{array}$ \\
\hline $\begin{array}{l}\text { Patir and } \\
\text { Karahan (2010) }\end{array}$ & $\begin{array}{l}\text { To determine potential } \\
\text { entrepreneurs and find ways to } \\
\text { lead them to the market and to } \\
\text { detect the problems in } \\
\text { entrepreneurship education and } \\
\text { produce solutions }\end{array}$ & $\begin{array}{l}\text { University students have sufficient } \\
\text { levels of entrepreneurship capacities } \\
\text { and that those who took } \\
\text { entrepreneurship education are more } \\
\text { likely to establish their own } \\
\text { businesses }\end{array}$ \\
\hline $\begin{array}{l}\text { Izedonmi and } \\
\text { Okafor (2010) }\end{array}$ & $\begin{array}{l}\text { To examine the effect of } \\
\text { entrepreneurial education on }\end{array}$ & $\begin{array}{l}\text { A positive relationship exists between } \\
\text { students' entrepreneurship } \\
\text { education and their entrepreneurial }\end{array}$ \\
\hline
\end{tabular}


INTERNATIONAL JOURNAL OF ACADEMIC RESEARCH IN BUSINESS AND SOCIAL SCIENCES Vol. 9, No. 6, June, 2019, E-ISSN: 2222-6990 @ 2019 HRMARS

\begin{tabular}{|c|c|c|}
\hline Author & Research Objective & Research Findings \\
\hline & $\begin{array}{l}\text { student's entrepreneurial } \\
\text { intentions. }\end{array}$ & $\begin{array}{l}\text { intentions. Knowledge and skills are } \\
\text { major influencing factors in the } \\
\text { student's entrepreneurial intentions }\end{array}$ \\
\hline $\begin{array}{l}\text { Ahmed et. al. } \\
\text { (2010) }\end{array}$ & $\begin{array}{l}\text { To study the impact of personality } \\
\text { traits, demographic characteristics } \\
\text { and entrepreneurship education } \\
\text { on entrepreneurial intentions of } \\
\text { university students }\end{array}$ & $\begin{array}{l}\text { Increased education level has an } \\
\text { impact on entrepreneurial intentions. } \\
\text { Years of study are found to be an } \\
\text { important predictor of } \\
\text { entrepreneurial intentions. Family } \\
\text { business experience is also one of the } \\
\text { important predictors of } \\
\text { entrepreneurial intention. }\end{array}$ \\
\hline Sanchez (2011) & $\begin{array}{l}\text { To test the effect of } \\
\text { entrepreneurship education } \\
\text { programs on the entrepreneurial } \\
\text { competencies and intention of } \\
\text { university students. }\end{array}$ & $\begin{array}{l}\text { Entrepreneurial education increases } \\
\text { students' competencies (self-efficacy, } \\
\text { pro-activeness and risk taking) and } \\
\text { intention towards self-employment }\end{array}$ \\
\hline $\begin{array}{l}\text { Byabashaija } \\
\text { and Katono } \\
(2011)\end{array}$ & $\begin{array}{l}\text { To examine the impact of } \\
\text { entrepreneurial education and } \\
\text { societal subjective norms on } \\
\text { entrepreneurial attitudes and } \\
\text { intentions of university students to } \\
\text { start a business }\end{array}$ & $\begin{array}{l}\text { Entrepreneurship education effects } \\
\text { perceptions of the desirability and } \\
\text { feasibility of entrepreneurship as a } \\
\text { career of choice and increases } \\
\text { students' self-confidence }\end{array}$ \\
\hline $\begin{array}{l}\text { Gözek and } \\
\text { Akbay (2012) }\end{array}$ & $\begin{array}{l}\text { To detect the entrepreneurial } \\
\text { intentions of prospective } \\
\text { entrepreneurs, the qualities they } \\
\text { need to have, the places they can } \\
\text { get support, and their problems }\end{array}$ & $\begin{array}{l}\text { Entrepreneurship is directly } \\
\text { proportional to education }\end{array}$ \\
\hline Yumuk (2013) & $\begin{array}{l}\text { To determine the factors playing a } \\
\text { role in the occupational } \\
\text { preferences of university students } \\
\text { and to explain the factors affecting } \\
\text { entrepreneurial intentions }\end{array}$ & $\begin{array}{l}\text { Entrepreneurship education has a } \\
\text { partial effect on entrepreneurial } \\
\text { intention }\end{array}$ \\
\hline Özdemir (2015) & $\begin{array}{l}\text { To determine the effects of } \\
\text { sociodemographic characteristics } \\
\text { of university students on their } \\
\text { entrepreneurial intentions and to } \\
\text { reveal whether their status of } \\
\text { receiving entrepreneurship courses } \\
\text { has an impact on entrepreneurial } \\
\text { intention }\end{array}$ & $\begin{array}{l}\text { Whether there are any entrepreneurs } \\
\text { in a student's family or not have an } \\
\text { effect on the "need for success" and } \\
\text { "creativity" dimensions of } \\
\text { entrepreneurial intention. Whether a } \\
\text { student has received } \\
\text { entrepreneurship education or not } \\
\text { have an effect on the "external locus } \\
\text { of control" dimension of }\end{array}$ \\
\hline
\end{tabular}


INTERNATIONAL JOURNAL OF ACADEMIC RESEARCH IN BUSINESS AND SOCIAL SCIENCES Vol. 9, No. 6, June, 2019, E-ISSN: 2222-6990 @ 2019 HRMARS

\begin{tabular}{|c|c|c|}
\hline Author & Research Objective & Research Findings \\
\hline & & $\begin{array}{l}\text { entrepreneurial intention. Those who } \\
\text { have not received entrepreneurial } \\
\text { education have a higher belief in an } \\
\text { external locus of control in } \\
\text { comparison with those who have } \\
\text { received. The entrepreneurship } \\
\text { courses have a contribution to the } \\
\text { awareness of students about } \\
\text { entrepreneurship }\end{array}$ \\
\hline
\end{tabular}

Sources: (Souitaris, Zerbinati and Al-Laham, 2007: 566-591; Balaban and Özdemir, 2008: 133-148; Wu and Wu, 2008: 752-774; Patır and Karahan, 2010: 27-44; Izedonmi and Okafor, 2010: 49-60; Ahmed et. al., 2010: 14-22; Sánchez, 2011: 239-254; Byabashaija and Katono, 2011: 127-144; Gözek and Akbay, 2012: 45-60; Yumuk, 2013: 96-120; Özdemir, 2015: 41-65)

Based on the discussions above, the following research propositions were developed:

Proposition 1: There is a significant relationship between entrepreneurial tendency and entrepreneurial intention.

Proposition 2: There is a mediating effect of entrepreneurial education on the relationship between entrepreneurial tendency and entrepreneurial intention.

\section{Conceptual Framework}

It is clearly evident that entrepreneurial education has an influence on entrepreneurial intention. Some studies indicate that entrepreneurial intention is best displayed when a student acquire adequate knowledge by obtaining tertiary qualifications. However, to what extent the similar intentions are manifested by a younger group of students pursuing their certificate or diploma qualification needed more empirical evidence before conclusive evidence can be derived. Therefore, this study is aiming to explore the relationship between entrepreneurial tendency and entrepreneurial intention among community college students who are in the early adoption of entrepreneurial endeavours. Additionally, the study also aims to understand the mediating effect of entrepreneurial education in the relationship between entrepreneurial tendency and entrepreneurial intention. In view of this, the following theoretical framework is proposed in this research. 
INTERNATIONAL JOURNAL OF ACADEMIC RESEARCH IN BUSINESS AND SOCIAL SCIENCES Vol. 9, No. 6, June, 2019, E-ISSN: 2222-6990 @ 2019 HRMARS

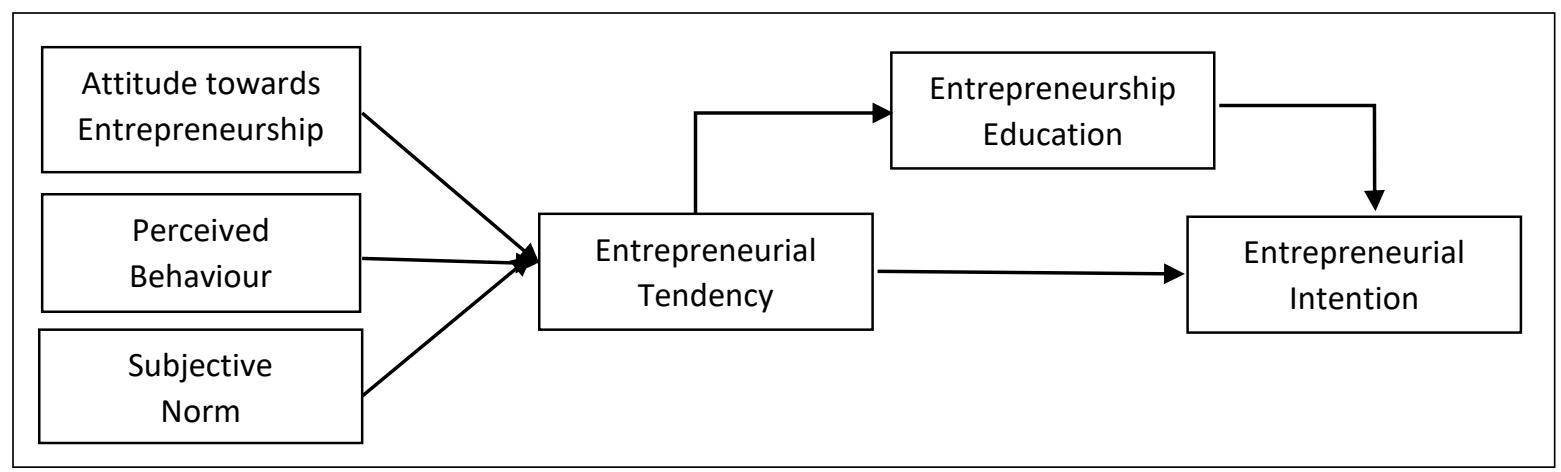

\section{Conclusion}

Figure 1: Conceptual Framework

Lately, entrepreneurship has gained tremendous devotion from various scholars and practitioners acknowledging the fact that it is important for economic growth apart from being a source of innovation (Urbano \& Aparicio, 2015). Entrepreneurship can be best described as a creative and innovative process (Guerrero, Rialp, \& Urbano, 2008). However, the cognitive state of intention is important for a potential entrepreneur as it creates a greater intensity towards the intention which makes one highly probable in venturing into entrepreneurial endeavours (Botsaris \& Vamvaka, 2016). Since entrepreneurship has been identified as an avenue for students' involvement, Malaysia has introduced entrepreneurship education in the curriculum to make the entrepreneurial venture as an alternative career to graduating students since they are the nascent entrepreneurs of the future. This conceptual paper recommends a theoretical framework to identify factors influencing entrepreneurial intention among community college students. More importantly, this study is an attempt to investigate the mediating effect of entrepreneurial education on the relationship between entrepreneurial tendency and entrepreneurial intention. Undeniably, this research suffers an empirical investigation. However, it is envisaged that this conceptual review could add to the current collection of literature and that it does provide a theoretical rationale in understanding the entrepreneurship phenomenon in the context of community colleges in their aspiration to create more nascent entrepreneurs. Perhaps the most important direction for future research is further extension and validation of this framework with an empirical investigation.

\section{References}

Abdul Aziz, R. (2003). Turning Malaysia into a global herbal producer: A personal perspective. Malaysia: Penerbit UTM.

Acs, Z. J., Autio, E., \& Szerb, L. (2014). National Systems of Entrepreneurship: Measurement Issues and Policy Implications. Research Policy, 43(3), 476-449.

Ahmed, I., Nawaz, M. M., Ahmad, Z., Shaukat, M. Z., Usman, A., ul-Rehman, W., \& Ahmed, N. (2010). Determinants of Students' Entrepreneurial Career Intentions: Evidence from Business Graduates. European Journal of Social Sciences, 15(2), 14-22. 
INTERNATIONAL JOURNAL OF ACADEMIC RESEARCH IN BUSINESS AND SOCIAL SCIENCES

Vol. 9, No. 6, June, 2019, E-ISSN: 2222-6990 @ 2019 HRMARS

Ajzen, I. (1991). The theory of planned behavior. Organizational Behavior and Human Decision Processes, 50(2), 179-211.

Ajzen, I. (2002). Perceived Behavioral Control, Self-Efficacy, Locus of Control, and the Theory of Planned Behavior. Journal of Applied Social Psychology, 32(4), 665-683.

Bandura, A. (1997). Social Foundation of Thought and Action. Englewood Cliffs, NJ: Prentice Hall.

Bird. B. (1988). Implementing entrepreneurial ideas: The case for intention. Academy of Management Review, 13(3), 442-453

Botsaris, C., \& Vamvaka, V. (2016). Attitude toward entrepreneurship: Structure, prediction from behavioral beliefs, and relation to entrepreneurial intention. Journal of the Knowledge Economy, $7(2), 433-460$.

Brana, S. (2008). Microcredit in France: Does gender matter? 5th Annual Conference-Nice. European Microfinance Network. Nice, France.

Byabashaija, W., \& Katono, I. (2011). The Impact of College Entrepreneurial Education on Entrepreneurial Attitudes and Intention to Start a Business in Uganda. Journal of Developmental Entrepreneurship, 16(1), 127-144.

Carter, S. \& Collinson, E. (1999). Entrepreneurship Education: Alumni Perceptions of the Role of Higher Education Institutions. Journal of Small Business and Enterprise Development, 6(3), 229239.

Cole, A. H. (1968). The entrepreneur: Introductory remarks. American Review of Economics, 58(2), 60-63.

Dollinger, M. (1995). Entrepreneurship: Strategies and Resources. Illinois: Irwin.

Douglas, E., \& Shepherd, D. (2002). Self-employment as a career choice: attitudes, entrepreneurial intentions, and utility maximization. Entrepreneurship Theory and Practice, 26(3), 81-90.

Ekpoh, U. I., \& Edet, A. O. (2011). Entrepreneurship Education and Career Intentions of Tertiary Education Students in Akwa Ibom and Cross River States, Nigeria. International Education Studies, 4(1), 172-178.

Global Entrepreneurship Monitor (2016). Global entrepreneurship monitor. GEM global reports. Retrieved fromhttp://www.gemconsortium.org/report/(Accessed29.06.2017)

Guerrero, M., Rialp, J., \& Urbano, D. (2008). The impact of desirability and feasibility on entrepreneurial intentions: A structural equation model. The International Entrepreneurship and Management Journal, 4(1), 35-50.

Hisrich, R. D. \& Peters P. P. (1995). Entrepreneurship: Starting, developing and managing a new enterprise, 3rd ed, London: Irwin.

Hisrich, R. D., Peters, M. P \& Shephard, D. A. (2008). Entrepreneurship (International Edition). Singapore: The McGraw-Hill Education Asia.

Izedonmi, P. F. \& Okafor, C. (2010). The Effect of Entrepreneurship Education on Students' Entrepreneurial Intentions. Global Journal of Management and Business Research, 10(6), 49-60.

Kalafatis, S. P., Pollard, M., East, R. \& Tsogas, M. H. (1999). Green marketing and Ajzen's theory of planned behavior: a cross-market examination. Journal of Consumer Marketing, 16(5), 441-460.

Katz, J., \& Gartner, W. B. (1988). Properties of emerging organizations. Academy of Management Review, 13(3), 429-441. 
INTERNATIONAL JOURNAL OF ACADEMIC RESEARCH IN BUSINESS AND SOCIAL SCIENCES

Vol. 9, No. 6, June, 2019, E-ISSN: 2222-6990 @ 2019 HRMARS

Keogh, W., \& Galloway, L. (2004). Teaching enterprise in vocational disciplines: Reflecting on positive experience. Management Decision, 42(3/4), 531-541

Kolvereid, L. (1996). Organisational employment versus self-employment: Reasons for career choice intentions. Entrepreneurship Theory and Practice, 20(3), p.23-31.

Krueger, N. \& Carsrud, A. L. (1993). Entrepreneurial Intentions: Applying the Theory of Planned Behaviour. Entrepreneurship and Regional Development, 5(4), 315-330

Krueger, N. F. Jr., Reilly, M. D., \& Carsrud, A. L. (2000). Competing models of entrepreneurial intentions. Journal of Business Venturing, 15(6/6), 411- 432.

Linan, F., \& Chen, Y. W. (2009). Development and cross-cultural application of a specific instrument to measure entrepreneurial intentions. Entrepreneurship Theory and Practice, 33(3), 593-617.

Linan, F., Urbano, D., \& Guerrero, M. (2007). Regional Variations in Entrepreneurial Cognitions: Startup Intentions of University Students in Spain. Paper presented at the Babson Conference, Madrid.

Maes, J., Leroy, H., \& Sels, L. (2014). Gender differences in entrepreneurial intentions: A TPB multigroup analysis at factor and indicator level. European Management Journal 32(5), 784-794.

Mohar, Y., Singh, M. S. \& Kamal, K. K. (2007). Relationship between psychological characteristics and entrepreneurial inclination: a case study of students at University Tun Abdul Razak (UNITAR). Journal of Asia Entrepreneurship and Sustainability, 3(2), 1-10.

Mumtaz, B. A. K, Munirah, S., \& Halimahton, K. (2012). The Relationship between educational support and entrepreneurial intentions in Malaysian Higher Learning Institution. Procedia - Social and Behavioral Sciences, 69(24), 2164-2173.

Buang, N. A. (2002). Asas keusahawanan. Petaling Jaya: Penerbitan Fajar Bakti.

Ozdemir, L. (2015). Kırgızistan-Türkiye Manas Üniversitesi Öğrencilerinin Girişimcilik Eğilimlerinin Sosyo-Demografik Özellikler Açısından Değerlendirilmesi, Suleyman Demirel University. The Journal of Faculty of Economics and Administrative Sciences, 20(1), 41-65.

Patır, S., \& Karahan, M. (2010). Girişimcilik Eğitimi ve Üniversite Öğrencilerinin Girişimcilik Profillerinin Belirlenmesine Yönelik Bir Alan Araştırması. Business and Economics Research Journal, 1(2), 2744.

Pretorius, M. (2000). Evaluation of a proposed training methodology to enhance micro and small business start-ups in South Africa. Proceedings: ICSB World Conference. Brisbane. Australia.

Sánchez, J. C. (2011). University training for entrepreneurial competencies: its impact on intention of venture creation. International Entrepreneurship and Management Journal, 7(2), 239-254.

Schaper, M., Volery, T., Weber, P., \& Lewis, K. (2010). Entrepreneurship and small business (3rd Pacific Rim edition). Milton, Queensland: John Wiley \& Sons.

Schumpeter, J. A. (1934). The Theory of Economic Development: An Inquiry into Profits, Capital, Credit, Interest and Business Cycle. Cambridge, MA: Harvard University Press.

Segal, G., Borgia, D., \& Schoenfeld, J. (2005). The motivation to become an entrepreneur. International Journal of Entrepreneurial Behaviour \& Research, 11(1), 42-57.

Shane, S., (2003). A General Theory of Entrepreneurship: The Individual-Opportunity Nexus. Elgar, Cheltenham, UK and Northampton, MA

Shapero, A., \& Sokol, L. (1982). The social dimensions of entrepreneurship. In C. Kent, D. Sexton, K.H. Vesper (Eds.). The encyclopedia of entrepreneurship (pp. 72-90). Englewood Cliffs, NJ: PrenticeHall. 
INTERNATIONAL JOURNAL OF ACADEMIC RESEARCH IN BUSINESS AND SOCIAL SCIENCES

Vol. 9, No. 6, June, 2019, E-ISSN: 2222-6990 (C) 2019 HRMARS

Souitaris, V., Zerbinati, S., \& Al-Laham, A. (2007). Do Entrepreneurship Programs Raise Entrepreneurial Intention of Science And Engineering Students? The Effect of Learning, Inspiration and Resources. Journal of Business Venturing, 22, 566-591.

Stevenson, H. H., Roberts, M. J. \& Grousbeck, H. I. (1989). New Business Ventures and the Entrepreneur, Irwin, Homewood, IL, 1989.

Thandi, H., \& Sharma, R. (2004). MBA students' preparedness for entrepreneurial efforts. Tertiary Education and Management, 10(3), 209-226.

Urbano, D., \& Aparicio, S. (2015). Entrepreneurship capital types and economic growth: International evidence. Technological forecasting and social change, 102, 34-44.

Van Auken, H., Stephens, P., Fry F. \& Silva, J. (2006). Role model influences on entrepreneurial intentions: A comparison between USA and Mexico. International Entrepreneurship and Management Journal, 2(3), 325-336.

Vesalainen, J. \& Pihkala, T. (1999). Motivation structure and entrepreneurial, intentions. In P. Reynolds et al. (Eds.), Frontiers of entrepreneurship research (pp. 73-87). Babson Park, MA: Babson College.

Wu, S., \& Wu, L. (2008). The impact of higher education on entrepreneurial intentions of university students in China. Journal of Small Business and Enterprise Development, 15(4), 752-774.

Yumuk, G. (2013). Turizm Bolumu Ogrencilerinin Girişimcilik Eğitimlerinin Girişimcilik Eğilimlerine Etkisi. Trakya Üniversitesi Iktisadi ve Idari Bilimler Fakültesi EDergi, 2(2), 96-120.

Mohd Makhbul, Z., \& Hasun, M. F. (2003). Menjadi usahawan: Panduan menubuhkan dan menguruskan perusahaan secara profesional. Bentong: PTS Publication \& Distribution. 